\title{
PENDAMPINGAN MANAJEMEN STRES PENDIDIK PAUD MENGHADAPI AKREDITASI DI PAUD SERIBU KUBAH TULUNGAGUNG
}

\section{ASSISTANCE OF STRESS MANAGEMENT OF PAUD EDUCATORS FACING ACCREDITATION IN PAUD SERIBU KUBAH TULUNGAGUNG}

\author{
Ahmad Fauzan \\ UIN Sayyid Ali Rahmatullah Tulungagung \\ Email: f2ahmadfauzan@gmail.com \\ (Diterima 12-08-2021; Disetujui 15-09-2021)
}

\begin{abstract}
ABSTRAK
Sekolah merupakan lembaga pendidikan yang memiliki berbagai program atau kegiatan. Komponen penting dalam sistem pendidikan nasional dalam pendidikan adalah siswa, guru dan kurikulum. Guru atau tenaga pendidik merupakan salah satu sumber daya manusia yang merupakan unsur penting dalam memberikan layanan pendidikan kepada masyarakat. Kualitas mutu layanan pendidikan yang baik memenuhi standar yang telah ditetapkan dalam sistem pendidikan nasional melalui program akreditasi lembaga pendidikan. Kegiatan akreditasi ini dapat memberikan tekanan kepada guru yang dapat berdampak pada kondisi fisik maupun psikologis yang dialami. Pengabdian ini diberikan kepada 15 orang guru di PAUD Seribu Kubah yang sedang mempersiapkan akreditasi. Kegiatan ini dilakukan guna memberikan edukasi mengenai stres, faktor dan strategi yang dapat dilakukan guru ketika menghadapi tekanan.
\end{abstract}

Kata Kunci: Manajemen Stres, Pendidik PAUD, Akreditasi

ABSTRACT

Schools are educational institutions that have various programs or activities. Students, teachers, and curriculum are important components in the national education system. Teachers or educators are one of the human resources which are an important element in providing educational services to the community. Good quality education services meet the standards set in the national education system through the accreditation program of educational institutions. This accreditation activity can put pressure on teachers which can have an impact on the physical and psychological conditions experienced. This service is given to 15 teachers at the PAUD Seribu Kubah who are preparing for accreditation. This activity is carried out to provide education about stress, factors, and strategies that teachers can do when facing pressure.

Keywords: Stress Management, PAUD Educators, Accreditation

\section{PENDAHULUAN}

Sekolah merupakan lembaga pendidikan yang memiliki berbagai program atau kegiatan. Komponen penting dalam sistem pendidikan nasional dalam pendidikan adalah siswa, guru dan kurikulum. Guru atau tenaga pendidik merupakan salah satu sumber daya manusia yang merupakan unsur penting dalam memberikan layanan pendidikan kepada masyarakat. Pendidikan yang baik memenuhi delapan standar-standar yang telah ditetapkan dalam sistem pendidikan nasional. Hal ini betujuan untuk mencapai mutu pendidikan yang diharapkan.

Mutu suatu layanan pendidikan dapat digolongkan berdasarkan tinjauan sistem, yaitu golongan proses, input, dan output. Tiga komponen tersebut menjadi fokus utama untuk dibuat program perbaikan satuan pendidikan secara kreatif dan konstruktif. Pemerintah telah memiliki program yang bernama akreditasi. Kegiatan akreditasi bertujuan untuk 
menilai kualitas mutu layanan satuan pendidikan. Jika baik hasil akreditasi suatu satuan pendidikan maka mutu satuan pendidikan akan semakin baik pula. Mutu yang dimaksud pada kegiatan akreditasi ini mengacu pada Permendikbud No 13/208 tentang BAN S/M dan BAN PAUD dan PNF (Kemdikbud RI, 2018).

Pada tahun 2020 ini BAN PAUD dan PNF melakukan moratorium dikarenakan adanya pandemik Covid-19 dan perbaikan sistem akreditasi. BAN PAUD dan PNF, melihat dua faktor moratorium tersebut, menyusun kembali semua kebijakan, program kerja dan mekanisme akreditasi yang akan dilaksanakan secara daring. Dalam hal ini akan menggunakan sistem aplikasi Sispena 3.0 untuk meningkatkan kualitas akreditasi. Selanjutnya dilaksanakan kegiatan Uji Coba yang bertujuan memelihara database dan menguji sistem aplikasi, yakni fokus pada dua aspek: (1) mencermati adanya persoalan sistem dalam Sispena 3.0; dan (2) melihat kenyamanan bagi pengguna dalam mempraktikkan pengisian dan penilaian akreditasi melalui Sispena 3.0 (Subekti, 2020).

Perubahan sistem akreditasi Sispena 3.0 ini menjadi tantangan para pengelola dan pendidik PAUD dalam mempersiapkan diri baik secara psikologis dan fisik. Tidak semua lembaga akan mengikuti uji coba sistem akreditasi. PAUD Seribu Kubah adalah salah satu satuan pendidikan di kabupaten Tulungagung yang terjaring menjadi peserta piloting uji coba sistem akreditasi Sispena 3.0. Hal ini memicu kepanikan tersendiri dikarenakan situasi pandemi yang mana kegiatan pembelajaran dilakasanakan dengan Belajar Dari Rumah (BDR) serta dokumen administrasi yang mereka miliki belum siap sepenuhnya.

Pendidik sebagai ujung tombak pembelajaran dan sebagai sasaran penilaian utama dalam pelaksanaan akreditasi harus segera menyiapkan administrasi sesuai standar akreditasi Sispena 3.0 yang mana mereka belum mendapatkan informasi detail sistem dan cara pelaksanaannya. Hal ini menjadi tekanan psikologis yang kuat bagi pendidik PAUD dalam kondisi pandemi, dimana kegiatan di sekolah ditiadakan, pendidik harus mempersiapkan semua keperluan akreditasi dalam waktu yang telah ditentukan. Kondisi tekanan yang dialami seseorang saat mengerjakan tugas atau pekerjaan di luar batas kemampuan yang dimiliki sehingga hal ini menyebabkan individu merasa cemas, tegang, dan stres. Sarafino mendefinisikan stres merupakan kondisi yang disebabkan oleh interaksi antara individu dengan lingkungan, memicu persepsi antara tuntutan yang berasal dari situasi yang bersumber pada sistem biologis, psikologis dan sosial individu (Sarafino \& Smith, 2017).

Dalam sebuah penelitian menunjukkan 24 pendidik mengalami kewalahan baik secara fisik dan psikis dalam menghadapi akreditasi, reaksi yang muncul adalah mudah 
marah, mudah merasa kesal, merasa khawatir, sulit tidur, mengalami sakit dan memikirkan tugas yang harus dipersiapkan untuk akreditasi. Hasil penelitian yang dilakukan di SMA Nuruzzaman IBS, terdapat beberapa hasil yakni, para pendidik yang melaksanakan akreditasi dapat dikatakan mengalami stres. Hal itu dilihat dan merujuk dari teori yang dikemukakan Andrew Goliszek. Hal itu terjadi tidak terlepas dari perasaan tertekan dan beban yang cukup berat yang dirasakan pendidik dalam menghadapi akreditasi (Dian \& Seno, 2019).

Salah satu wujud kontribusi perguruan tinggi adalah pengabdian kepada masyarakat yang dilakukan oleh sivitas akademika. Kegiatan pengabdian kepada masyarakat dapat dilakukan berupa pelatihan, sosialisasi dan pemberdayaan masyarakat yang ditujukan untuk masyarakat tanpa komersialisasi. Demikian juga dengan bentuk pengabdian yang dilakukan yakni sosialisasi tentang menangani stres pada pendidik PAUD saat akreditasi mempunyai tujuan untuk peningkatakan kemampuan pendidik PAUD dalam usaha mengelola kondisi psikologis terutama saat akreditasi. Kegiatan akreditasi yang tidak dapat dihindari memaksa para pendidik PAUD untuk menyesuikan diri dengan sumberdaya yang dimiliki. Berikut merupakan tujuan dari pengabdian yakni: 1. Memberikan pengetahuan baru bagi peserta yang tidak berasal dari latar belakang psikologi terkait dengan pemahaman stres. 2. Memberikan pemahaman bahwa kesehatan mental sama pentingnya dengan kesehatan fisik.

Kegiatan pengabdian ini memiliki manfaat bagi antara lain, pertama, individu memiliki pemahaman mengenai pentingnya kesehatan mental yang perlu mulai disadari sebagaimana kesehatan fisik. Kedua, menghasilkan masyarakat khususnya pendidik yang memiliki pemahaman mengidentifikasi stres dan strategi yang dapat digunakan untuk mengatasinya. Hal ini penting mengingat pendidik merupakan ujung tombok lembaga dalam menghadapi langsung peserta didik dan tugas administrasi yang perlu keterampilan dalam mengelola tuntutan yang muncul baik dari dalam diri atau luar yang bisa memicu stres.

Sebagai upaya guna mengelola kondisi psikologis yang muncul di saat akreditasi ini, maka perlu solusi guna meminimalkan risiko yang dapat muncul. Pemecahan masalah dapat dilakukan dengan memberikan pemahaman kepada pendidik PAUD dalam menghadapi akreditasi. Pendidik PAUD sebagai objek akreditasi perlu mendapatkan pengetahuan dan pemahaman tentang pengelolaan stres. Melalui sosialisasi ini pendidik PAUD mampu mengenal pengertian, jenis, aspek dan dampak serta strategi pengelolaan stres. Diharapkan pendidik PAUD dengan belajar menyadari bahwa diri mengalami stres, 
mengidentifikasi penyebab stres, identifikasi sumber daya yang dimiliki, sebagai langkah dalam upaya mencegah kondisi stres yang berkepanjangan yang dapat berkontribusi pada munculnya permasalahan psikologis lain yang lebih kompleks.

\section{BAHAN DAN METODE}

Kegiatan pengabdian kepada masyarakat tentang "Menangani stres pada pendidik PAUD saat Akreditasi” ditawarkan kepada pengelola PAUD Seribu Kubah Tulungagung. Setelah melakukan diskusi dengan pengelola PAUD Seribu Kubah, akhirnya mendapat kesepakatan dengan pihak pengelola PAUD Seribu Kubah dengan pelaksanaan kegiatan pengabdian kepada masyarakat dilaksanakan pada hari Sabtu, tanggal 28 November 2020. Tempat pelaksanaan pengabdian kepada masyarakat tentang "Menangani stres pada pendidik PAUD saat Akreditasi” berada di PAUD Seribu Kubah. PAUD Seribu Kubah berada di sebelah utara pusat pemerintahan kabupaten Tulungagung. Tepatnya pada desa Sukowidodo kecamatan Karangrejo kabupaten Tulungagung Jawa Timur.

Pelaksanaan pengabdian ini pada masa pandemi, sehingga peserta yang terlibat dibatasi jumlahnya. Pesertanya adalah terdiri atas pendidik PAUD Seribu Kubah Karangrejo 10 orang guru TK dan 5 orang guru KB, jumlah peserta semuanya adalah 15 orang. Kegiatan pengabdian dilaksanakan dengan pola komunikasi secara langsung atau tatap muka. Pertama, penyampaian materi oleh narasumber dan pelaksanaan komunikasi secara langsung diatur oleh moderator. Setelah pemaparan materi selesai dilanjutkan dengan sesi tanya jawab dan diselingi kuiz. Kemudian diakhiri dengan penutupan.

\section{HASIL DAN PEMBAHASAN}

Tahap pertama adalah melakukan survei di satuan PAUD yang akan melaksanakan akreditasi yakni lembaga PAUD Seribu Kubah yang dipilih. Pelaksana pengabdian dan pihak sekolah berdiskusi mengenai terkait dengan pengabdian yang akan dilakukan di lembaga tersebut. Berdasarkan diskusi, pelaksanaan pengabdian dilakukan pada 28 November 2020. Pemilihan satuan pendidikan PAUD Seribu Kubah berdasarkan bahwa lembaga ini sedang mengajukan akreditasi ke BAN PNF dan PAUD Provinsi Jawa Timur dan teridentifikasi pendidik mengalami tekanan dalam menyiapkan akreditasi berdasarkan hasil asesmen yang dilakukan oleh pelaksana pengabdian.

Tahap kedua adalah pelaksanaan edukasi tentang manajemen stres. Kegiatan pengabdian kepada masyarakat mengenai "Menangani stres pada pendidik PAUD saat Akreditasi" yang diadakan oleh Fakultas Ushuluddin, Adab, dan Dakwah IAIN 
Tulungagung memberikan pemahaman pengetahuan baru bagi peserta yang belum mengetahui mengenai stres. Para peserta diajak untuk mengenali kondisi dirinya dengan pertanyaan ringan.

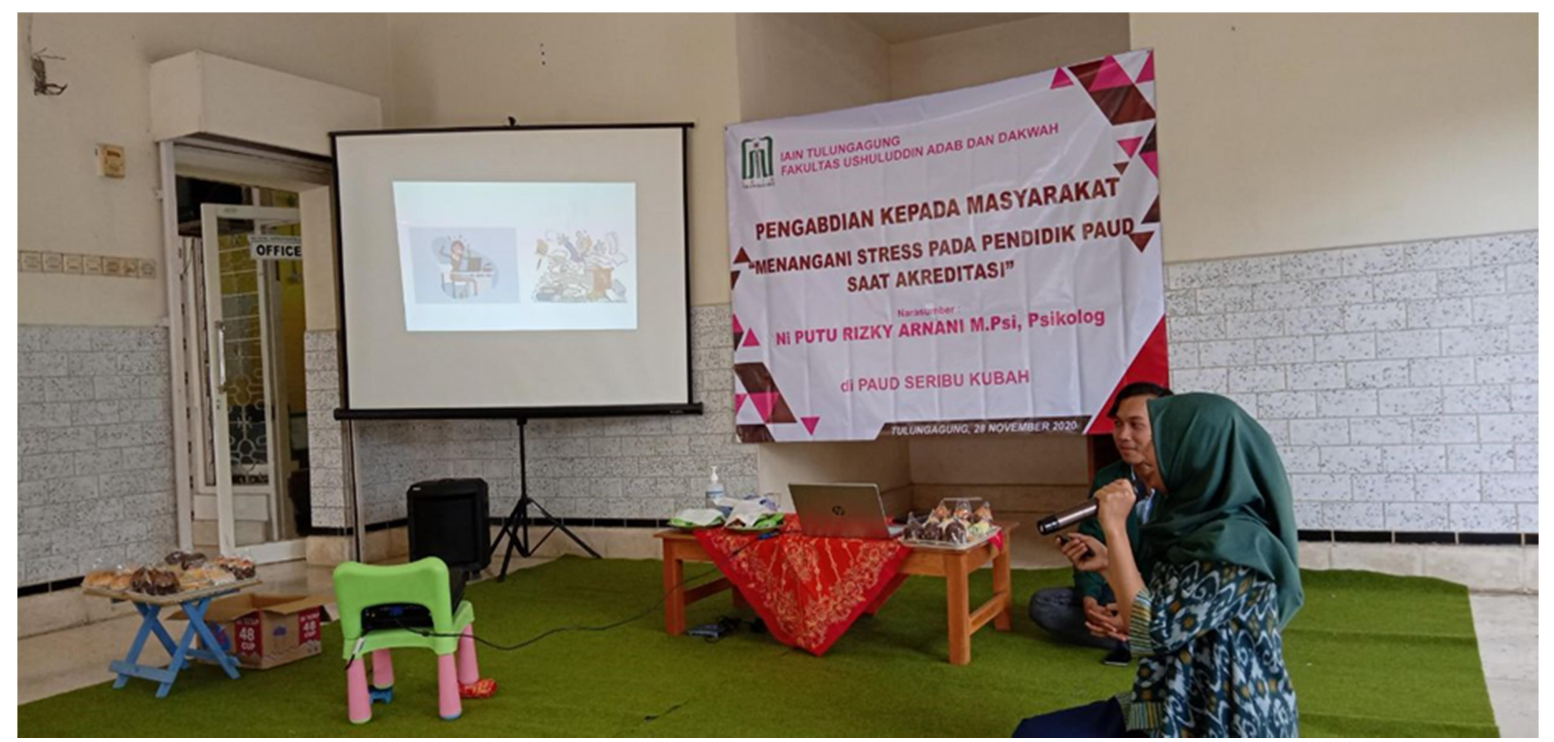

Gambar 1. Penyampaian Materi

Setelah peserta mengidentifikasi kondisi dirinya, materi disampaikan dalam kegiatan pengabdian kepada masyarakat ini terdiri atas: pengertian stres, macam-macam stres, penyebab stres, dan cara mengelola stres.

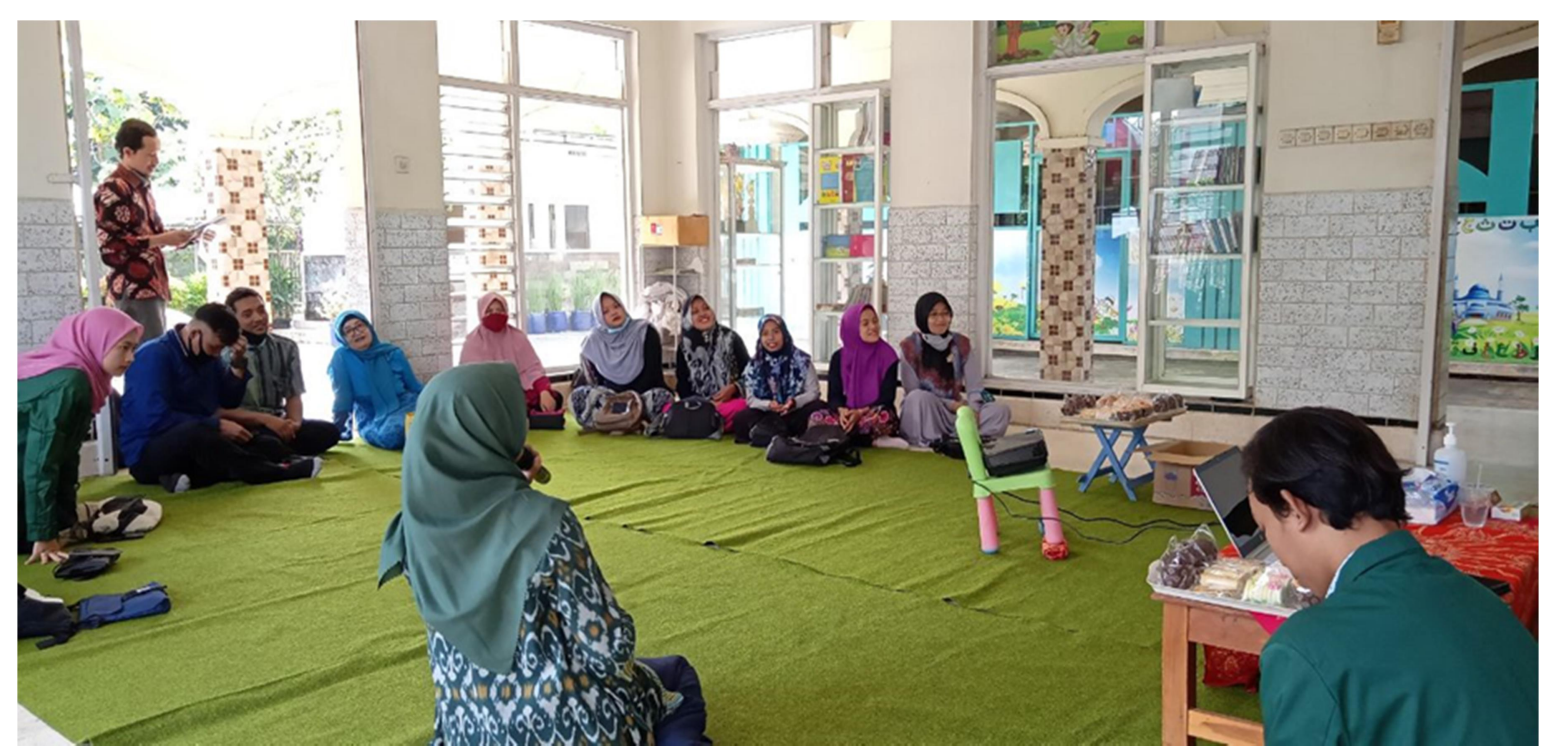

Gambar 2. Peserta Menyimak Materi 
Selama proses pemaparan materi, berdasarkan hasil observasi menunjukkan bahwa peserta memahami bahwa stres adalah reaksi baik fisik atau psikis ketika individu menghadapi ancaman, tekanan atau perubahan lingkungan yang menuntut untuk beradaptasi. Stres merupakan reaksi normal yang dapat dialami oleh seluruh individu. Selain menjelaskan mengenai faktor-faktor yang mempengaruhi, identifikasi dan hal yang bisa dilakukan ketika mengalami stres. Selama proses diskusi mengenai manajemen stres, peserta bertanya mengenai perbedaan stres dan depresi, serta langkah yang bisa dilakukan ketika mengalami kondisi stres.

\section{KESIMPULAN DAN SARAN}

Pengabdian kepada masyarakat dengan judul "Menangani stres pada pendidik PAUD saat Akreditasi” telah dilaksanakan, bertempat di PAUD Seribu Kubah Desa Sukowidodo Kecamatan Karangrejo. Dari hasil kegiatan ini dapat disimpulkan: Pertama, pendidik PAUD mendapatkan pemahaman tentang konsep psikologis stres. Mulai dari pengertian, jenis, sumber, aspek, dan cara mengelola stres telah disampaikan dalam kegiatan pengabdian. Kedua, pendidik PAUD mempunyai gambaran diri terkait dengan aplikasi pemahaman materi. Dalam menghadapi stres, pendidik mampu mengidentifikasi stres yang dialami. Selanjutnya dengan tindakan yang tepat dapat mengelola stres sehingga kondisi tekanan akreditasi dapat dikelola dan tidak menjadi stres yang berkepanjangan.

\section{DAFTAR PUSTAKA}

Dian, D., \& Seno, I. M. (2019). Tingkat Stress Pendidik (Guru) Dalam Menghadapi Akreditasi Sekolah. Itqan, 10(2), 133-139.

Kemdikbud RI. (2018). Permendikbud RI No. 13 tahun 2018 tentang Badan Akreditasi Nasional Sekolah/Madrasah dan Badan Akreditasi Nasional Pendidikan Anak Usia Dini dan Pendidikan Nonformal.

Sarafino, E. P., \& Smith, T. W. (2017). Health Psychology: Biopsychosocial Interactions Ninth Edition.

Subekti, A. (2020). Uji Coba Sistem Untuk Pengembangan Akreditasi. Www.Banpaudpnf.Kemdikbud.Go.Id. https://banpaudpnf.kemdikbud.go.id/berita/uji-coba-sistem-untuk-pengembanganakreditasi 